\title{
The correlation between spermatozoa morphometry and the testosterone levels in the epididymis of aceh cow
}

\author{
Sri Wahyuni ${ }^{*}$, Gholib Gholib ${ }^{2}$, Rizki Maulana ${ }^{2}$, Dasrul Dasrul ${ }^{3}$, Tongku N. Siregar ${ }^{3}$, Hamny Hamny ${ }^{1}$, Muhammad \\ Jalaluddin ${ }^{1}$, Fadli A. Gani ${ }^{1}$, Mudhita Z. Ritonga ${ }^{1}$, and Muslim $\mathrm{Akmal}^{4}$ \\ ${ }^{1}$ Laboratory of Anatomy, Faculty of Veterinary Medicine, Universitas Syiah Kuala, Banda Aceh 23111, Indonesia \\ ${ }^{2}$ Laboratory of Physiology, Faculty of Veterinary Medicine, Universitas Syiah Kuala, Banda Aceh 23111, Indonesia \\ ${ }^{3}$ Laboratory of Reproduction, Faculty of Veterinary Medicine, Universitas Syiah Kuala, Banda Aceh 23111, Indonesia \\ ${ }^{4}$ Laboratory of Histology, Faculty of Veterinary Medicine, Universitas Syiah Kuala, Banda Aceh 23111, Indonesia
}

\begin{abstract}
The objective of this study was to determine the correlation between spermatozoa morphometry and testosterone concentration in the epididymal caput, corpus, and cauda of aceh cattle. The epididymal sperm swab slides were stained using Williams's staining to examined the morphology and morphometry of spermatozoa whereas the level of testosterone from epididymal caput, corpus, and cauda extract was measured using enzyme-linked immunosorbent assay (ELISA). The data of sperm morphology were presented descriptively whereas the data of sperm morphometry and testosterone concentration were analyzed using one way ANOVA. Pearson correlation test was conducted to know the correlation between the total length of spermatozoa (TLS) and testosterone concentration in three parts of epididymis. The result showed that the sperm morphology in caput, corpus, and cauda of epididymis was not different statistically. The TLS of aceh cattle at caput, corpus, and cauda epididymis were $69,70 \pm 0,8 \mu \mathrm{m}, 70,90 \pm 0.39 \mu \mathrm{m}$, and $72,98 \pm 0.74 \mu \mathrm{m}$ respectively and statistically different $(\mathrm{p}<0.05)$. In addition, the concentration of testosterone in caput, corpus, and cauda epididymis were $9,92 \pm 3,76 \mathrm{ng} / \mathrm{g}, 16.96 \pm 13,22 \mathrm{ng} / \mathrm{g}$, and $15,63 \pm 11.80 \mathrm{ng} / \mathrm{g}$ respectively and also not different among three parts of epididymis $(\mathrm{p}>0.05)$. The positive correlation $(\mathrm{r}=0.413, \mathrm{p}=0.416)$ was found between TLS and testosterone concentration at caput whereas in corpus and cauda those correlation were negative and not different (corpus: $r=-0.638, p=0.172$ and cauda: $r=-0.719, p=0,108$ ). In conclusion, the longest-sized spermatozoa found in the cauda epididymis are mature spermatozoa where the maturation process optimally takes place in caput epididymis. Testosterone found in the epididymis of aceh cow can be used as an alternative source of testosterone.
\end{abstract}

Keywords: epididymis, spermatozoa, testosterone, and aceh cow.

\section{Introduction}

The epididymis is a long and convoluted ductus for spermatozoa transports from seminiferous tubule of the testes to the ductus deferens. This organ divided into three parts, namely the caput, corpus, and cauda epididymis that firmly attached to the testicles and separated by tunica albuginea [1]. Histologically, the mucosa of the epididymal duct is covered by the epithelial layer which plays a role in the maturation of spermatozoa to become forward motile and acquire their fertilizing ability the ovum during epididymal transit [2]. Each part of the epididymis secretes specific protein, which important to sperm maturation [3]. Additionally, the epididymis is a place for the absorption of fluid from the testicular seminiferous tubule, maturation, storage, and distribution of spermatozoa into the ductus deferens before mixing with fluid that secreted by accessory sex glands [4].

Maintenance of structure and function of the ductus epididymis is regulated by the androgen hormone which is mostly derived from the testes [5]. In the epididymis tissue, testosterone bound to androgen binding protein (ABP) and then enters the principal cells that contain the testosterone receptor [6] whereas free testosterone may enter the principal cells by passive diffusion and subsequently reduced to dihydrotestosterone (DHT) by $5 \alpha$ reductase. Testosterone concentration in the epididymal lumen is several-fold higher than in the circulation where the concentration is decline to the caudal part of epididymis [7]. The presence of androgens, i.e. testosterone and DHT in the tissue and epididymal fluid has been reported by Jean-Faucher et al. [8]. The difference between the concentration of both hormones in the caput, corpus, and cauda epididymis in adult mice is known by measuring epididymis tissue extract using radioimmunoassay (RIA) technique.

The epididymis of aceh cows is one of the slaughterhouse waste that can be used as an alternative source of testosterone. It is necessary to explore the content of the testosterone in the epididymal tissue of aceh cow which has never been reported. Testosterone content

* Corresponding author: sriwahyuni@unsyiah.ac.id 
in the tissue of the caput, corpus, and cauda epididymis could be determined by measuring the concentration of the hormone using the enzyme-linked immunosorbent assay (ELISA) technique. Furthermore, the spermatozoa morphometry in each part of epididymis could be measured to determine the role of testosterone on spermatozoa maturation along epididymal ductus. Therefore, the objective of this study was to determine the morphometry of spermatozoa and concentration of testosterone, and also the correlation between spermatozoa morphometry and testosterone concentration in the tissue of caput, corpus, and cauda epididymis. The results of this study can be used as supporting information for other studies related to the potency of testosterone in epididymal tissue extracts to improve the spermatozoa quality in aceh cows.

\section{Materials and Methods}

\subsection{Samples collection}

Three pairs of epididymis organs of adult aceh cows in healthy conditions were collected from a local slaughterhouse. All epididymis was divided into caput, corpus, and cauda epididymis and then prepared to obtained epididymal fluids and continued to epididymal tissue. Epididymal fluids from caput, corpus, and cauda were used for measuring the morphometry of spermatozoa, whereas epididymal tissue was taken from those parts of epididymis and then extracted for measuring testosterone concentration.

\subsection{Spermatozoa Morphometry}

Epididymal fluids that has been collected from each part of epididymis were mixed with $2 \%$ eosin solution (ratio 1:4) and one drop of fluid was thinly covered on the slide's surface. Afterward, slides were dried using a hotplate, observed and measured the spermatozoa morphometry that included the length and wide of the sperm head, and also the tail length (from midpiece to end piece) [9]. Measurement of spermatozoa was performed by using a light microscope (Meiji MT4200L Japan) that equipped by an Infinity Analyzer software on 25 normal spermatozoa per slide.

\subsection{Epididymal tissue extraction}

For extraction, epididymal tissue was taken from each part of epididymis (caput, corpus, and cauda) each $100 \mathrm{mg}$ and then homogenized, washed with $1 \mathrm{ml}$ phosphate buffer saline (PBS), and subsequently stored overnight in the freezer at $-20^{\circ} \mathrm{C}$. Samples were then thawed after freeze (freeze-thawing) to break the cell membrane of epididymal tissue. The freeze-thawing process was done twice and then samples homogenized was centrifuged with $1200 \mathrm{xg}$ of speed for 10 minutes at $2-8^{\circ} \mathrm{C}$. The supernatant was stored at $-20^{\circ} \mathrm{C}$ until the measurement of testosterone level.

\subsection{Hormone Analysis}

Hormone analysis was performed according to the instruction from the manufacturer (Testosterone ELISA kit, DRG, EIA-1559 GmbH, Germany). This assay has been validated for Aceh cattle [10]. Before analysis, epididymal tissue extract was diluted 1:4 using aquabidestilates sterile. A standard solution with a range of 0.2 to $16 \mathrm{ng} / \mathrm{ml}$ was prepared. Briefly, duplicate $25 \mu \mathrm{l}$ aliquots of extract samples were assayed along with $25 \mu \mathrm{l}$ aliquots standard (range 0.2-16 $\mathrm{ng} / \mathrm{ml}$ ) and control solution on microtitre plates that coated with a monoclonal mouse antibody of testosterone. Subsequently, $200 \mu$ l enzyme conjugate was added to each well and the mixture incubated for 60 minutes at room temperature. Following incubation, the microtiter plates washed four times with washing solution and blotted dry. After that, a $200 \mu \mathrm{l}$ substrate solution (tetramethylbenzidine) was added to each well. Afterward, the plates re-incubated for 15-20 minutes at room temperature. The enzyme reaction was stopped with $100 \mu 10.5 \mathrm{M} \mathrm{H}_{2} \mathrm{SO}_{4}$ in each well. Finally, absorbance was measured at $450 \mathrm{~nm}$ on an automatic plate reader (ELISA reader) and testosterone level was calculated automatically using the MPM6 program.

\subsection{Data analysis}

Data of spermatozoa morphometry were analyzed descriptively, whereas analysis of variance (ANOVA) was applied to determined the comparison of levels of testosterone on the three parts of the epididymis (caput, corpus, and cauda) were analyzed using one way analysis of variance (ANOVA).A pearson correlation test was then performed to determine the correlation between testosterone levels and spermatozoa morphometry.

\section{Results and Discussion}

\subsection{Morphometry of Spermatozoa}

The length and width of spermatozoa head (HL and HW) in each part of epididymis were not different statistically $(p>0.05)$. However, there were significant differences $(p<0.05)$ of tail length (TL) and the total length of spermatozoa (TLS) in each part of epididymis. In cauda epididymis, the tails of spermatozoa were longer $(63.11 \pm 0.35 \mu \mathrm{m})$ than in caput $(59,87 \pm 0,67 \mu \mathrm{m})$ and corpus $(60,92 \pm 0,39 \mu \mathrm{m})$ epididymis. In addition, the longest of TLS also found in the cauda epididymis. According to Soler et al. [11], spermatozoa undergo a maturation process in the epididymal duct namely caput dan corpus epididymis. The mature spermatozoa subsequently are stored in the cauda epididymis before ejaculated. Cooper [12] reported that the mature spermatozoa characterize by changes in their morphology and motility to be able to fertilize an ovum. These developments occur under the influence of epididymal secretions. Spermatozoa produced from defective spermiogenesis may unable to respond adequately to the epididymal environment. From this study, spermatozoa 
found in the cauda were longer in size than in caput and corpus due to the spermatozoa being mature. The total length of aceh cow spermatozoa found in this study $(72.98 \pm 0.74 \mu \mathrm{m})$ is the same as the length of bali cattle spermatozoa $(72.17 \pm 0.25 \mu \mathrm{m})$ as reported by Arifiantini et al. [9].

Table 1. Morphometry of spermatozoa in caput, corpus, and cauda epididymis of aceh cow.

\begin{tabular}{cccc}
\hline \multirow{3}{*}{$\begin{array}{c}\text { Spermatozoa } \\
\text { Morphometry }\end{array}$} & \multicolumn{3}{c}{ Epididymis } \\
\cline { 2 - 4 } & Caput $(\mu \mathrm{m})$ & $\begin{array}{c}\text { Corpus } \\
(\mu \mathrm{m})\end{array}$ & Cauda $(\mu \mathrm{m})$ \\
\hline HL & $9.83 \pm 0.45$ & $9.98 \pm 0.25$ & $9.87 \pm 0.48$ \\
HW & $5.86 \pm 0.23$ & $5.99 \pm 0.32$ & $5.86 \pm 0.26$ \\
TL & $59.87 \pm 0.67^{\mathrm{a}}$ & $60.92 \pm 0.39^{\mathrm{b}}$ & $63.11 \pm 0.35^{\mathrm{c}}$ \\
TLS & $69.70 \pm 0.8^{\mathrm{a}}$ & $70.90 \pm 0.39^{\mathrm{b}}$ & $72.98 \pm 0.74^{\mathrm{c}}$ \\
\hline
\end{tabular}

HL: head length; HW: head width, TL: tail length, and TLS: total length spermatozoa.

\subsection{Epididymal Testosterone Concentration}

Based on hormone analysis, testosterone concentration in caput, corpus, and cauda were $9.92 \pm 3.76 \mathrm{ng} / \mathrm{g}$, $16.96 \pm 13.22 \mathrm{ng} / \mathrm{g}$, and $15.63 \pm 11.80 \mathrm{ng} / \mathrm{g}$ respectively, where those concentrations were not different statistically ( $p>0.05$ ). However, testosterone in corpus and cauda were higher than in caput. It indicates that the spermatozoa maturation occurred optimally in the corpus than in caput, whereas in cauda, testosterone required for maintenance mature spermatozoa before transfer to the ductus deferens. The low concentration of testosterone in the caput epididymis, it is suspected that large amounts of testosterone have been converted by $5 \alpha$-reductase into DHT. The process takes place inside the nucleus of the principal cell. According to Turner et al. [7], free testosterone in epididymal ductus is reduced to form DHT, where the DHT is the most important androgen involved in the spermatozoa maturation [6]. High levels of testosterone in corpus probably correspond to the number of these hormone receptors in the corpus epididymis, especially in the principal cells. This has been reported in the adult mice epididymis that those receptors are distributed in large amounts in the principal cells of corpus than in caput epididymis. In addition to the epididymis, testosterone in high concentrations is also found in the ductus deferens of adult mice $(64.5 \pm 7.5 \mathrm{ng} / \mathrm{g}$ in proximal part and $26.9 \pm 4.3 \mathrm{ng} / \mathrm{g}$ in caudal part) [8]. However, the concentration of testosterone in the ductus deferens tissue of aceh cows in this study was not measured. According to the results of measurement, epididymis tissue containing testosterone can be used as a potent source of that hormone which can be used in improving the spermatozoa quality. In addition to epididymis, the ductus deferens of aceh cows can also be used as a tissue that produces testosterone, but its potency as testosterone source still requires further study.

\subsection{Correlation Between Epididymal Spermatozoa Morphometry and Testosterone Concentration}

Based on correlation test, we found a positive correlation between the TLS and testosterone concentration in caput epididymis $\left(r=0.413\right.$ and $\left.R^{2}=0.170\right)$ although not significantly different $(p=0.416)$. Furthermore, the correlation also found in the corpus epididymis, however the correlation was negative $\left(r=-0.638\right.$ and $\left.R^{2}=0.407\right)$ and also not different statistically $(\mathrm{p}=0.172)$. The same correlation was also found in the cauda epididymis $(r=-$ 0.719 and $\left.R^{2}=0.516\right)$, but not different $(p=0.108)$.
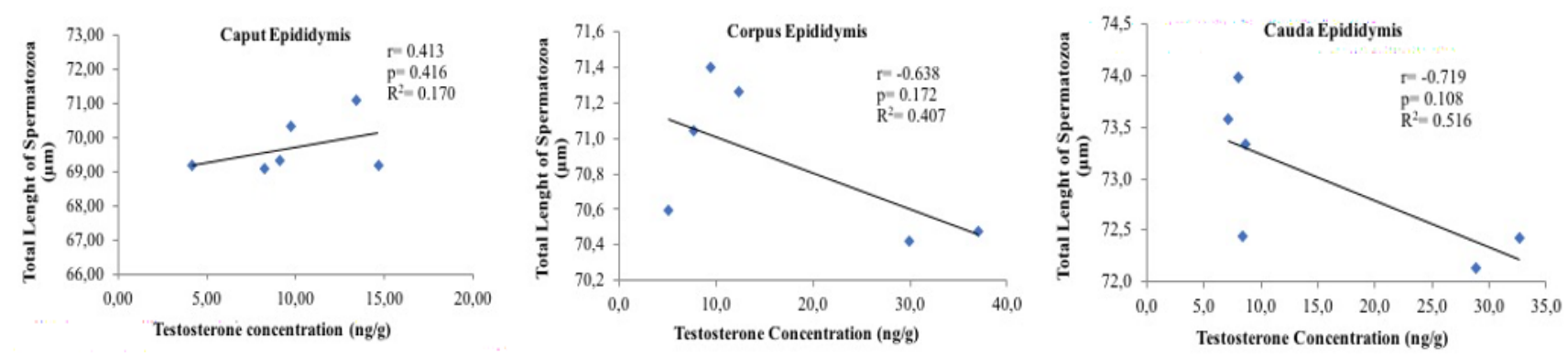

Figure 1. Correlation between morphometry spermatozoa (total length of spermatozoa/TLS) and testosterone concentration in the caput, corpus, and cauda epididymis of aceh cows.

The positive correlation between TLS and testosterone concentration found in the caput epididymis assumes that in this part the role of testosterone is needed for spermatozoa maturation after the hormone reduced into DHT. However, in the corpus, the negative correlation was found as well as in the cauda epididymis. Although the maturation process still occurs in the corpus, in caput that process it is though to be more active, whereas, in the cauda, testosterone is required for maintaining the motility of mature spermatozoa before entering the ductus deferens. Negative correlation in both corpus and cauda indicates that the maturation process has decreased especially in the cauda, so that testosterone which is converted to DHT decreases.

Spermatozoa maturation in the epididymis involves the role of cells lining the epididymis surface. Testosterone does not have a direct role in the maturation of spermatozoa, but the hormones serve to provide stimulation to some cells in the ductus, although in low concentration. There are five cell types found in epididymis tissue, namely the principal, halo, basal, clear, 
and narrow cells. From the five cells, only the principal and basal cells have components of androgen receptors (AR), while it is not yet known whether there is AR in halo, clear, or narrow cells. Basal cells function is to produce the lipoprotein $\mathrm{E}$ and alcohol dehydrogenase, regulating electrolytes and water transport that carried out by the principal cells [6]. Principal cells are the most active cells in transportation, ion secretion, synthesis and secretion of proteins. The products secreted through these cells have a major role in the characteristics of the spermatozoa [13]. Testosterone which binds to androgen receptors in the nucleus of principal cells of the epididymal mucosal epithelium will then activate the cells to produce the specific protein needed for the spermatozoa maturation process [14]. Therefore, the size of principal cells is different along epididymal epithelium as reported by Wahyuni et al. [15] in the epididymis of javan muntjac (Muntiacus muntjac muntjac) where the highest size of the cells was found in caput and then decrease in corpus and cauda epididymis. According to Kohane et al. [16], in each part of epididymis, there are differences in the amount of specific epididymal proteins (SEP). The SEP compounds show a high rate of caput, corpus, and cauda epididymis. This indicates that the function of the principal cells as a producer of SEP in the epididymal ductus with respect to the amount of protein produced for the spermatozoa maturation

\section{Conclusion}

The longest-sized spermatozoa found in the cauda epididymis are mature spermatozoa where the maturation process takes place in caput epididymis that marked by the lower testosterone concentration. Testosterone found in the epididymis of aceh cow can be used as an alternative source of testosterone.

\section{References}

1. Dyce KM, Sack WO, Wensing CGJ: Textbook of Veterinary Anatomy. Philadelphia, London. Saunders. 2002.

2. Sullivan R, Mieusset R: The human epididymis: its function in sperm maturation. Hum. Reprod. Update. 2016; 22(5):574-587.

3. Li JY, Wang HY, Liu Q, et al. : Transcriptome analysis of a cDNA library from adult human epididymis. DNA Res. 2008; 15:115-122.
4. Wroble KH, Bergmann M: Male Reproductive System. Dellmann's Textbook of Veterinary Histology. Iowa: Blackwell Publishing. 2006.

5. Robaire B, Hamzeh M: Androgen action in the epididymis. J. Androl. 2011; 32(6): 592-599.

6. Robaire B, Hinton BT, Orgebin-Crist M: The Epididymis. In: Knobil and Neill's Physiology of Reproduction. St. Louis, MO: Elsevier Academic Press. 2006.

7. Turner TT, Ewing LL, Jones CE, et al. Androgens in male rat reproductive tract fluid: hypophysectomy and steroid replacement. Am. J. Physiol. 1985; 248-280.

8. Jean-Faucher C, Berger M, Gallon C, et al. : Regional differences in the testosterone to dihydrotestosterone ratio in the epididymis and vas deferens of adult mice. J. Reprod. Fert. 1986; 76: 537-543.

9. Arifiantini RI, Wresdiyati T, Retnani EF: Kaji banding morfologi spermatozoa sapi bali (Bos sondaicus) menggunakan pewarnaan Williams, eosin, eosin nigrosine, dan formolsaline. J Sain. Vet. 2006; 24(1): 6570.

10. Gholib G, Wahyuni S, Akmal M, et al.: The validation of a commercial enzyme-linked immunosorbent assay and the effect of freeze-thaw cycles of serum on the stability of cortisol and testosterone concentrations in Aceh cattle [version 1; peer review: 1 approved, 1 approved with reservations]. F1000Research 2019, 8:1220.

11. Sooler C, Perez-Sanchez F, Schulze H, et al. : Objective evaluation of the morphology of human epididymal sperm heads. Int. J. Androl. 2000; 23: 77-84.

12. Cooper TG: The epididymis, cytoplasmic droplets, and male fertility. Asian J. Androl. 2011; 13:130-138.

13. Dufresne J, St-Pierre N, Viger SR, et al. : Characterization of a novel rat epididymal cell line to study epididymal function. Endocrinology. 2004; 146(11):4710-4720.

14. Cornwall GA: New insights into epididymal biology and function. Hum. Reprod. Update. 2009; 15(2):218-227.

15. Wahyuni S, Agungpriyono S, Agil M, et al: Histologi dan histomorfometri testis dan epididimis muncak (Muntiacus muntjak muntjak) pada periode ranggah keras. J. Vet. 2012;13(3): 211-219.

16. Kohane CA, Fernanda MC, Echeverria G, et al.: Interaction of Proteins of Epididymal Origin with Spermatozoa. Biol. Reprod. 1980; 23:737-742. 